\title{
Evaluation of antimalarial activity of leaves of Acokanthera schimperi and Croton macrostachyus against Plasmodium berghei in Swiss albino mice
}

\author{
Tigist Mohammed ${ }^{1}$, Berhanu Erko ${ }^{2}$ and Mirutse Giday ${ }^{2 *}$
}

\begin{abstract}
Background: Malaria is one of the most important tropical diseases and the greatest cause of hospitalization and death. Recurring problems of drug resistance are reinforcing the need for finding new antimalarial drugs. In this respect, natural plant products are the main sources of biologically active compounds and have potential for the development of novel antimalarial drugs. A study was conducted to evaluate extracts of the leaves of Croton macrostachyus and Acokanthera schimperi for their in vivo antimalarial activity.

Methods: The plants were selected based on their ethnomedicinal information. Acute and sub- acute toxicity studies of the crude extracts were carried out in Swiss albino mice. To assess the effect of extracts of the plants on the parasite, a 4-day suppressive standard test was performed using Plasmodium berghei (ANKA strain). Data were analyzed using paired t-test and ANOVA.

Results: In acute toxicity study, the two plants extracts did not show any sign of toxicity up to $2000 \mathrm{mg} / \mathrm{kg}$. In sub-acute toxicity study, both plants did not exhibit any hematological change and mortality throughout the observation period up to the highest dose of $1000 \mathrm{mg} / \mathrm{kg}$ given daily. Extracts of the leaves of both plants significantly $(P<0.05)$ suppressed parasitaemia in dose dependent manner at all dose levels.

Conclusions: The findings may support the traditional use of the plants to treat malaria. Further pharmacological, toxicological and phytochemical studies are, however, required to evaluate the potential of the plants towards the development of new antimalarial agent.
\end{abstract}

Keywords: Croton macrostachyus, Acokanthera schimperi, Antimalarials, Plasmodium berghei, in vivo, Ethiopia

\section{Background}

Malaria is a major public-health problem in the world; transmission primarily being common in tropical and subtropical regions [1]. According to WHO, globally, there were about 216 million and 207 million cases of malaria in 2010 and 2012, respectively, and estimated 655,000 and 627,000 deaths in 2010 and 2012, respectively [2,3].

In Ethiopia, though some improvements were recently achieved, malaria is still the leading cause of morbidity and mortality $[4,5]$. Ethiopia is also one of the most malaria epidemic-prone countries in Africa where rates of morbidity and mortality increase 3-5 folds during epidemics [6].

\footnotetext{
* Correspondence: mirutseg@yahoo.com

${ }^{2}$ Aklilu Lemma Institute of Pathobiology, Addis Ababa University, P.O. Box

1176, Addis Ababa, Ethiopia

Full list of author information is available at the end of the article
}

Multi-drug resistant strains of the parasite to antimalarial drugs proved to be a challenging problem in malaria control in most parts of the world [1]. These recurring problems render development and promotion of phytomedicines as alternative solution to malaria control [7]. Medicinal plants have been playing a vital role in the treatment of malaria for centuries [8] and have always been considered to be a possible alternative and rich source of new drugs. Today, herbal products are being used worldwide in a variety of healthcare settings, and as home remedies [9]. Over 1200 plant species from 160 families are used to treat malaria and fever in endemic countries [10].

It is estimated that about $80 \%$ of the population in Ethiopia is still dependent on traditional medicines [11]. However, scientific studies on the status of use of phytomedicine, preparation of crude extracts and isolation of 
active principles is very minimal [12]. Croton macrostachyus and Acokanthera shimperi are two of the plants that are traditionally used for malarial treatment in Ethiopia $[13,14]$. A study reported that methanol extracts of the fruits of C. macrostachyus have shown substantial antimalarial activities against $P$. falciparum in vitro with $\mathrm{IC}_{50}$ value of $0.94 \mu \mathrm{gm} / \mathrm{mL}$ [15]. An in vivo study also showed that methanol extract of the fruits of Croton macrostachyus has significant suppressive effect against $P$. berghei [16]. An in vivo study conducted on Acokanthera oppositifolia in Kenya and in vitro study conducted on Croton zambesicus in Cameroon, taxonomically related species to A. schimperi and $C$. macrostachyus, respectively, demonstrated an interesting antiplasmodial activity on $P$. falciparum $[17,18]$. The objective of this study, therefore, was to investigate antimalarial effect of aqueous and methanol extracts of the leaves of $A$. schimperi and C. macrostachyus in mice infected with chloroquine sensitive strain of $P$. berghei. The study was conducted at the Endod and Other Medicinal Plants Research Unit of the Aklilu Lemma Institute of Pathobiology, Addis Ababa University.

\section{Methods}

\section{Plant material collection sites}

Young leaves of Acokanthera schimperi were collected from Bishan Gari Lodge area (Buku Wolda) about $20 \mathrm{~km}$ off the Addis Ababa - Hawasa road in December 2012 (reference number TM02-2012) and that of Croton macrostachyus from the compound of the Aklilu Lemma Institute of Pathobiology (ALIPB) in October, 2012 (reference number: TM01-2012). The plants were identified by the second author, the botanist at the Aklilu Lemma Institute of Pathobiology, Addis Ababa University, and voucher specimens were deposited at the Institute. The plants were selected based on previous reports of their traditional use for treating malaria in Ethiopia $[13,14]$.

\section{Preparation of crude plant extracts}

The leaves of Acokanthera schimperi and Croton macrostachyus were washed thoroughly with running tap water and each plant material was reduced to small fragments. The plant samples were air-dried at room temperature under shade, and ground into powder using pestle and mortar. The powdered plant materials were packed in plastic bags until extraction. The coarsely powdered plant materials were weighed using sensitive balance and repeatedly extracted in water and methanol in maceration flasks. Powdered plant parts (140 gm of Croton macrostachyus and $155 \mathrm{gm}$ of Acokanthera schimperi) were mixed in distilled water and methanol separately in 1:10 (w/v) and placed on orbital shaker at $130 \mathrm{rpm}$ for 24 hours in water and for 72 hours in methanol at room temperature. Then, the extracts, were filtered through Whatman (no 1, diameter $150 \mathrm{~mm}$, England). The methanol extract was concentrated at $40^{\circ} \mathrm{C}$ with a rotary evaporator (Buchi, Switzerland) in distillation flask to eliminate methanol from the crude extract and concentrated further to dryness in a water bath at $40^{\circ} \mathrm{C}$. For aqueous extract, residual water was removed by lyophilizer (Heto Power Dry LL3000, Wagtech, Denmark) at $-56^{\circ} \mathrm{C}$. Then, the extracts were stored in tightly closed bottle containers in a refrigerator at $4^{\circ} \mathrm{C}$ until they were used for the experiment [19-21].

\section{Experimental animals and parasite inoculation \\ Experimental animals and parasite strain}

Male Swiss albino mice, 5-7 weeks of age and 23-38 gm of weight were obtained from the Ethiopia Health and Nutrition Research Institute (EHNRI). They were kept in the animal care facility of the Aklilu Lemma Institute Pathology, Addis Ababa University, for one week prior to the initiation of the experiments for acclimatization to laboratory conditions. The mice were kept at room temperature in humid environment and were exposed to 12 hours light and 12 hours darkness. The mice were given water and standard food pellets every 24 hours. In vivo antimalarial testing in mice was done using chloroquine sensitive strain of Plasmodium berghei (ANKA strain) obtained from EHNRI. On weekly basis, the parasites were maintained by serial passage of blood from infected mice having a parasitamia level of $20-30 \%$ to non-infected ones.

\section{Parasite inoculation}

Albino mice previously infected with $P$. berghei were used as donor animals. The parasitaemia of the donor mice was first determined and parasitized erythrocytes were obtained by cardiac puncture using ethyl ether as anesthesia and diluted in physiological saline $(0.9 \%)$. The dilution was made based on the parasitaemia of the donor mice and the RBC count of normal mice in such a way that $1 \mathrm{~mL}$ blood contains $5 \times 10^{7}$ infected erythrocytes [22]. Each mouse was inoculated by intraperitoneal injection with a blood suspension $(0.2 \mathrm{~mL})$ containing $1 \times 10^{7}$ parasitized erythrocytes.

\section{In vivo toxicity test of the crude plant extracts}

The crude methanol and aqueous extracts of Croton macrostachyus and Acokanthera schimperi intended for the antimalarial test against $P$. berghei were evaluated for their acute toxicity in non-infected Swiss albino mice aged 6-8 weeks and weighing 23-38 g. For each extract, 10 mice were used by randomly dividing them into two groups of 5 mice per group. The mice were starved 3-4 hours before the experiment began with only water allowed and 1-2 hours after the extract was given [23]. Then, the mice in group 1 were given orally $0.2 \mathrm{~mL}$ of $2000 \mathrm{mg} / \mathrm{kg}$ body weight of the extract in single dose in $\mathrm{dH} 2 \mathrm{O}$. The mice in the control groups received $0.2 \mathrm{~mL}$ of vehicle of the extract $(\mathrm{dH} 2 \mathrm{O})$. Then, the mice were observed continuously for 30 minutes, followed by 4 
hourly observation for 24 hours and once a day for the next 13 days, for any manifestation of toxicity [23].

For sub-acute toxicity studies, weight and haematological parameters were determined before and after treatment. These include, packed cell volume (PCV), white blood cells count (WBC) and haemoglobin ( $\mathrm{Hb})$. A hand-held scale reader for PCV, Hemacytometer (Hawksley improved neubauer double cell) for WBC and haemoglobin meter (HemoCue model $201^{+}$, Angelholm, Sweden) for $\mathrm{Hb}$ were used for the determination. The extracts in each case were administered orally for four days (i.e. D0 to D4) using gavages [23]. The mice were grouped randomly, five mice per group. The mice in group I, II and III were given orally 500,750 and $1000 \mathrm{mg} / \mathrm{kg}$ body weight in single dose volume of $0.2 \mathrm{~mL}$ of each extract, respectively and control group received $0.2 \mathrm{~mL}$ of $\mathrm{dH} 2 \mathrm{O}$. The data was recorded on day 0 and day 4 (12 hours after administration of the last dose) with regards to reduction in PCV and $\mathrm{Hb}$, weight losses and $\mathrm{WBC}$, following which, the mice were closely observed for one month.

\section{In vivo antimalarial screening}

Schizontocidal activity was evaluated by the 4-day suppressive standard test [24]. Male Swiss albino mice weighing 24-35 grams were randomly divided into five groups of five mice per cage for each extract. All mice were infected with $P$. berghei on the first day (D0). Treatment commenced 3 hours after infection on day 0 and then continued daily for four days (i.e. from day 0 to day 3). The mice in the three treatment groups received extract from the Acokanthera schimperi and Croton macrostachyus $0.2 \mathrm{~mL}(200 \mathrm{mg} / \mathrm{kg}$, $400 \mathrm{mg} / \mathrm{kg}$, and $600 \mathrm{mg} / \mathrm{kg}$ ) of each extract. Group IV (negative control) received the vehicle $\left(\mathrm{dH}_{2} \mathrm{O}\right)$, while the fifth group received the standard antimalarial drug (chloroquine) $25 \mathrm{mg} / \mathrm{kg}$, with the same amount of volume $(0.2 \mathrm{~mL})$, daily for 4 days. The plant extracts and the standard drug were administered through intragastric route using standard tube to ensure safe ingestion of the extracts and the drug [23]. On the fifth day (D4), blood samples were collected from tail snip of each mouse [25] and thin smears were prepared and stained with $10 \%$ Giemsa solution. Then, the slides were examined under the microscope and parasitaemia determined by counting minimum of five fields per slide (500 RBC), for negative smear up to 100 field [26]. The smears were counted blindly by technician. Percent parasitaemia and percentage of suppression was calculated using the formula indicated in $[19,27]$.

$\%$ Suppression = Parasitaemia in negative control$\frac{\text { parasitaemia in treated group } \times 100}{\text { Parasitaemia in negative control }}$
$\%$ Parasitaemia $=\frac{\text { Number of Parasitized } R B C \times 100}{\text { Total } R B C \text { counted }}$

In acute toxicity testing, change in body weight of individual mice was determined and recorded before and after extract administration [23], while evaluation of antimalarial activity and sub toxicity testing, body weight of each mouse was measured before infection (day 0) and continuously for four days.

Packed cell volume measurement was done before infection on day 0 and on day 4 . Blood was collected from tail of each mouse in heparinized microhaematocrit capillary tubes filled up to 3/4th of their length. Then, the blood was centrifuged using microhematocrit centrifuge at 12,000 rpm for 5 minutes [28] and measured using a hand scale reader.

In addition, mortality of mice was monitored daily and the number of days was recorded for each mouse in the treatment and control groups throughout the follow up period.

\section{Data analysis}

Data were analyzed using computer software SPSS, version 16. Results of the study were expressed as a mean \pm standard error of the mean $(\mathrm{M} \pm \mathrm{SEM})$. Statistical significance was determined by one way analysis of variance (ANOVA) with multiple comparison tests (Post Hoc/ Tukey's test/HSD) to compare parameters within groups. Two tailed paired t-test was used to compare mean PCV, Hb, WBC and body weight before and after treatment. All data were analyzed at a 95\% confidence interval $(\alpha=0.05)$.

\section{Ethical consideration}

The study obtained ethical clearance from Institutional Review Board (IRB) of Aklilu Lemma Institute of Photobiology, Addis Ababa University. The mice were handled in humane accordance to the National Guidelines for handling laboratory animals for its scientific and academic merits.

\section{Results \\ Extraction yield of plants}

The methanol and aqueous extracts of Acokanthera schimperi showed the highest yield with $37.4 \%$ and $23.4 \%$, followed by methanol extract of Croton macrostachyus with $17.42 \%$ and that of water extract $4.6 \%$.

\section{Acute toxicity test}

In the in vivo acute toxicity studies of the plant extracts, there were no gross physical and behavioral changes; including, rigidity, sleep, diarrhea, depression, abnormal 
secretion and hair erection for 24 hours and no mortality occurred within the observation period of two weeks.

\section{Sub-acute toxicity test}

Methanol and aqueous extracts of Croton macrostachyus on day 4 showed no statistically significant difference $(\mathrm{P}>0.05)$ in all the hematological parameters mentioned above as compared to that of day 0 (Table 1). No mortality was observed in all treatment groups of both extracts and there was no statistical significant difference ( $\mathrm{P}>0.05)$ on body weight in methanol extract. Though, significant $(\mathrm{P}<0.05)$ bodyweight loss at the highest dose i.e. $1000 \mathrm{mg} / \mathrm{kg}$ (from $30.20 \mathrm{gm}$ to $25.90 \mathrm{gm}$ ) and body weight gain at $500 \mathrm{mg} / \mathrm{kg}$ (from $31.34 \mathrm{gm}$ to 33.58 gm) in aqueous extract and in negative control group (from 26.54 gm to $29.36 \mathrm{gm}$ ) was observed.

In sub-acute toxicity studies of methanol and water extracts of $A$. schimperi, when day 4 was compared to day 0 at a given dose levels $(500,750,1000 \mathrm{mg} / \mathrm{kg})$, no mortality was observed in any treatment group (Table 2). There was no significant difference $(\mathrm{P}>0.05)$ observed on hematological parameters (PCV and $\mathrm{Hb}$ ) and in the body weight of animals treated with both extracts and control group.

Table 1 Sub-acute toxicity effects of methanol and aqueous extracts of Croton macrostachyus

\begin{tabular}{|c|c|c|c|c|c|}
\hline Extract & Dose & Parameters & Day 0 & Day 4 & P-Value \\
\hline \multirow[t]{16}{*}{ Methanol } & 500 mg & Body weight(gm) & $33.00 \pm 2.59$ & $32.34 \pm 2.91$ & 0.628 \\
\hline & & PCV (\%) & $54.60 \pm 1.29$ & $54.20 \pm 1.62$ & 0.840 \\
\hline & & WBC $\left(\mathrm{mm}^{3}\right)$ & $7360 \pm 1591.34$ & $10300 \pm 250.49$ & 0.114 \\
\hline & & $\mathrm{Hb}$ & not determined & not determined & \\
\hline & 750 mg & Body weight (gm) & $34.66 \pm 2.29$ & $35.92 \pm 2.13$ & 0.085 \\
\hline & & PCV (\%) & $51.60 \pm 0.93$ & $50.20 \pm 0.66$ & 0.404 \\
\hline & & WBC $\left(\mathrm{mm}^{3}\right)$ & $5180.00 \pm 908.93$ & $7470.00 \pm 314.88$ & 0.720 \\
\hline & & $\mathrm{Hb}$ & not determined & not determined & \\
\hline & $1000 \mathrm{mg}$ & Body weight(gm) & $36.56 \pm 1.10$ & $33.14 \pm 1.76$ & 0.124 \\
\hline & & PCV (\%) & $52.20 \pm 1.96$ & $52.20 \pm 0.86$ & 0.852 \\
\hline & & WBC $\left(\mathrm{mm}^{3}\right)$ & $9420.00 \pm 489.03$ & $9840.00 \pm 1259.41$ & 0.647 \\
\hline & & $\mathrm{Hb}$ & not determined & not determined & \\
\hline & NC & Body weight (gm) & $35.86 \pm 0.56$ & $40.12 \pm 0.97$ & 0.007 \\
\hline & & PCV (\%) & $52.00 \pm 0.89$ & $52.40 \pm 0.60$ & 0.587 \\
\hline & & WBC $\left(\mathrm{mm}^{3}\right)$ & $9700 \pm 921.95$ & $5500 \pm 916.79$ & 0.004 \\
\hline & & $\mathrm{Hb}$ & not determined & not determined & \\
\hline \multirow[t]{16}{*}{ Aqueous } & 500 mg & Body weight (gm) & $31.34 \pm 0.56$ & $33.58 \pm 0.72$ & 0.002 \\
\hline & & PCV (\%) & $55.4 \pm 1.50$ & $50.80 \pm 2.33$ & 0.079 \\
\hline & & WBC $\left(\mathrm{mm}^{3}\right)$ & $5530.00 \pm 501.65$ & $8870.00 \pm 1750.90$ & 0.152 \\
\hline & & $\mathrm{Hb}$ & not determined & not determined & \\
\hline & 750 mg & Body weight (gm) & $31.94 \pm 1.09$ & $29.12 \pm 2.02$ & 0.072 \\
\hline & & PCV (\%) & $55.00 \pm 1.18$ & $53.60 \pm 0.87$ & 0.245 \\
\hline & & WBC $\left(\mathrm{mm}^{3}\right)$ & $9760.0 \pm 932.12$ & $13610 \pm 1581.41$ & 0.72 \\
\hline & & $\mathrm{Hb}$ & not determined & not determined & \\
\hline & $1000 \mathrm{mg}$ & Body weight (gm) & $30.20 \pm 1.49$ & $25.90 \pm 2.38$ & 0.018 \\
\hline & & PCV (\%) & $55.40 \pm 2.14$ & $57.60 \pm 1.12$ & 0.282 \\
\hline & & WBC $\left(\mathrm{mm}^{3}\right)$ & $4700.00 \pm 470.11$ & $9730.00 \pm 1503.46$ & 0.53 \\
\hline & & $\mathrm{Hb}$ & not determined & not determined & \\
\hline & NC & Body weight (gm) & $26.54 \pm 1.16$ & $29.36 \pm 1.52$ & 0.021 \\
\hline & & PCV (\%) & $54.60 \pm 0.75$ & $47.40 \pm 0.81$ & 0.007 \\
\hline & & WBC $\left(\mathrm{mm}^{3}\right)$ & $9630 \pm 1260.22$ & $8000 \pm 1832.01$ & 0.54 \\
\hline & & $\mathrm{Hb}$ & not determined & not determined & \\
\hline
\end{tabular}


Table 2 Sub-acute toxicity effects of methanol and aqueous extracts of Acokanthera schimperi

\begin{tabular}{|c|c|c|c|c|c|}
\hline Extract & Dose & Parameters & Day 0 & Day 4 & P-Value \\
\hline \multirow[t]{16}{*}{ Methanol } & $500 \mathrm{mg}$ & Body weight (gm) & $31.74 \pm 2.16$ & $33.76 \pm 2.08$ & 0.162 \\
\hline & & PCV (\%) & $54.60 \pm 0.75$ & $52.80 \pm 1.50$ & 0.195 \\
\hline & & WBC & not determined & not determined & \\
\hline & & $\mathrm{Hb}(\mathrm{g} / \mathrm{dL})$ & $16.36 \pm 0.55$ & $15.38 \pm 0.43$ & 0.052 \\
\hline & $750 \mathrm{mg}$ & Body weight (gm) & $30.38 \pm 0.59$ & $31.68 \pm 0.84$ & 0.094 \\
\hline & & PCV (\%) & $55.40 \pm 0.40$ & $50.20 \pm 2.18$ & 0.057 \\
\hline & & WBC & not determined & not determined & \\
\hline & & $\mathrm{Hb}(\mathrm{g} / \mathrm{dL})$ & $17.10 \pm 0.32$ & $16.32 \pm 0.63$ & 0.074 \\
\hline & $1000 \mathrm{mg}$ & Body weight (gm) & $32.22 \pm .1 .54$ & $31.70 \pm 1.72$ & 0.073 \\
\hline & & PCV (\%) & $52.40 \pm 0.75$ & $49.80 \pm 2.04$ & 0.395 \\
\hline & & WBC & not determined & not determined & \\
\hline & & $\mathrm{Hb}(\mathrm{g} / \mathrm{dL})$ & $16.46 \pm 0.27$ & $14.68 \pm 0.63$ & 0.109 \\
\hline & NC & Body weight (gm) & $29.04 \pm 1.82$ & $30.80 \pm 1.59$ & 0.078 \\
\hline & & PCV (\%) & $52.40 \pm 0.98$ & $51.20 \pm 1.07$ & 0.109 \\
\hline & & WBC & not determined & not determined & \\
\hline & & $\mathrm{Hb}(\mathrm{g} / \mathrm{dL})$ & $16.58 \pm 0.79$ & $15.48 \pm 0.65$ & 0.097 \\
\hline \multirow[t]{16}{*}{ Aqueous } & $500 \mathrm{mg}$ & Body weight (gm) & $30.42 \pm 1.45$ & $31.52 \pm 1.30$ & 0.327 \\
\hline & & PCV (\%) & $53.30 \pm 1.41$ & $50.20 \pm 0.66$ & 0.156 \\
\hline & & WBC & not determined & not determined & \\
\hline & & $\mathrm{Hb}(\mathrm{g} / \mathrm{dL})$ & $16.66 \pm 0.38$ & $14.86 \pm 0.35$ & 0.052 \\
\hline & $750 \mathrm{mg}$ & Body weight (gm) & $31.34 \pm 2.34$ & $31.88 \pm 2.11$ & 0.573 \\
\hline & & PCV (\%) & $53.10 \pm 1.33$ & $49.40 \pm 1.25$ & 0.083 \\
\hline & & WBC & not determined & not determined & \\
\hline & & $\mathrm{Hb}(\mathrm{g} / \mathrm{dL})$ & $16.30 \pm 0.72$ & $14.96 \pm 0.77$ & 0.123 \\
\hline & $1000 \mathrm{mg}$ & Body weight (gm) & $31.60 \pm 2.36$ & $32.90 \pm 2.21$ & 0.147 \\
\hline & & PCV (\%) & $54.48 \pm 0.96$ & $51.20 \pm 2.15$ & 0.227 \\
\hline & & WBC & not determined & not determined & \\
\hline & & $\mathrm{Hb}(\mathrm{g} / \mathrm{dL})$ & $17.10 \pm 0.51$ & $15.54 \pm 0.43$ & 0.123 \\
\hline & NC & Body weight (gm) & $29.04 \pm 1.82$ & $30.80 \pm 1.59$ & 0.078 \\
\hline & & WBC & not determined & not determined & \\
\hline & & PCV (\%) & $52.40 \pm 0.98$ & $51.20 \pm 1.07$ & 0.109 \\
\hline & & $\mathrm{Hb}(\mathrm{g} / \mathrm{dL})$ & $16.58 \pm 0.79$ & $15.48 \pm 0.65$ & 0.097 \\
\hline
\end{tabular}

The results are expressed as mean \pm SEM $(n=5) ; N C=$ negative control; $P C V=$ packed cell volume; $W B C=$ white blood cells; $\mathrm{Hb}=$ haemoglobin; $P>0.05$ is not significant.

\section{Antimalarial activities}

\section{Effect of crude extracts on PCV and body weight}

Methanol and aqueous extracts of Croton macrostachyus did not prevent PCV reduction due to parasitemia. Significant reduction of PCV on day 4 as compared to day $0(\mathrm{p}<0.05)$ was observed in both treatment and in negative control groups. But, no significant $(\mathrm{p}>0.05)$ change was observed in body weight of all groups. For chloroquine treatment groups, no significant change ( $\mathrm{P}>0.05)$ was observed in all parameters (Table 3 ).

PCV and body weight measurements on day 4 indicated that both methanol and aqueous extracts of
Acokanthera schimperi prevented significantly $(\mathrm{P}<0.05)$ PCV reduction and body weight loss at all dose levels (200 mg, $400 \mathrm{mg}, 600 \mathrm{mg}$ ) due to parasitemia. In negative control, there was significant $(\mathrm{P}<0.05)$ reduction in $\mathrm{PCV}$ on day 4 , though no bodyweight change observed (Table 4).

Effect of crude extracts of leaves of Croton macrostachyus and Acokanthera shimperi on parasitaemia and mean survival time of mice

Methanol and aqueous extracts of Croton macrostachyus and Acokanthera shimperi showed dose dependent chemosuppressive effect at various doses in mice infected with 
Table 3 Effect of crude methanol and aqueous extracts of Croton macrostachyus on body weight and PCV of $P$. berghei infected mice

\begin{tabular}{|c|c|c|c|c|c|}
\hline \multirow{2}{*}{$\begin{array}{l}\text { Extract/ } \\
\text { Treatments }\end{array}$} & \multirow{2}{*}{$\begin{array}{l}\text { Doses } \\
(\mathrm{mg} / \\
\mathrm{kg})\end{array}$} & \multicolumn{2}{|c|}{ PCV } & \multicolumn{2}{|c|}{ Body weight in grams } \\
\hline & & Day0 & Day4 & Day0 & Day4 \\
\hline \multirow[t]{3}{*}{ Methanol extracts } & 200 & $54.60 \pm 0.51$ & $45.60 \pm 1.17^{a}$ & $30.06 \pm 0.50$ & $30.06 \pm 0.61^{*}$ \\
\hline & 400 & $55.70 \pm 0.30$ & $46.00 \pm 2.98^{a}$ & $29.68 \pm 0.51$ & $28.68 \pm 0.10^{*}$ \\
\hline & 600 & $54.68 \pm 0.63$ & $46.00 \pm 1.30^{a}$ & $30.60 \pm 1.55$ & $30.04 \pm 1.43^{*}$ \\
\hline Distilled water & $1 \mathrm{~mL}$ & $55.00 \pm 0.84$ & $44.00 \pm 1.80^{\mathrm{a}}$ & $28.78 \pm 1.10$ & $28.18 \pm 1.07^{*}$ \\
\hline Chloroquine & 25 & $53.20 \pm 1.59$ & $49.00 \pm 1.09^{*}$ & $29.96 \pm 0.62$ & $29.80 \pm 0.66^{*}$ \\
\hline \multirow[t]{3}{*}{ Aqueous extracts } & 200 & $55.60 \pm 0.24$ & $43.20 \pm 3.18^{a}$ & $30.20 \pm 1.75$ & $28.18 \pm 1.07^{*}$ \\
\hline & 400 & $55.60 \pm 0.24$ & $45.60 \pm 1.36^{a}$ & $28.32 \pm 1.60$ & $28.66 \pm 2.26^{*}$ \\
\hline & 600 & $55.60 \pm 0.24$ & $45.00 \pm 1.92^{\mathrm{a}}$ & $29.00 \pm 0.95$ & $28.48 \pm 1.65^{*}$ \\
\hline Distilled water & $1 \mathrm{~mL}$ & $55.00 \pm 0.84$ & $44.00 \pm 1.80^{a}$ & $28.78 \pm 1.10$ & $28.18 \pm 1.07^{*}$ \\
\hline Chloroquine & 25 & $53.20 \pm 1.59$ & $49.00 \pm 1.09^{*}$ & $29.96 \pm 0.62$ & $29.80 \pm 0.66^{*}$ \\
\hline
\end{tabular}

Results presented as mean $\pm S D ; n=5 ;{ }^{*}=$ there was no significant difference, between Day-0 and Day- $4(P>0.05)$; $a=$ there was a significant difference between Day-0 and Day-4 $(P<0.05)$.

Plasmodium berghei parasite. The mice treated with chloroquine were completely free from the parasites on day four in all the experiments.

The crude methanol extracts of Croton macrostachyus significantly suppressed $(\mathrm{P}<0.05)$ parasitaemia at all dose levels compared to the negative control groups but did not improve survival time significantly $(\mathrm{P}>0.05)$ (Table 5).

Similarly, the aqueous extracts of Croton macrostachyus significantly reduced parasitaemia compared to the negative control group. The highest significant parasitaemia suppression $(\mathrm{P}<0.05)$ was observed for this extract although it did not improve the mean survival time (Table 6).

Tables 7 and 8 show a summary of parasitaemia suppression (\%) of A. schimperi for mice on day 4. Both aqueous and methanol extracts showed significant suppression of parasitaemia $(\mathrm{P}<0.05)$. The mean survival time of treatment group ranged from $7.00 \pm 1.73$ up to $10.60 \pm 0.51$ days, whereas that of negative control was $6.2 \pm 0.20$ days. The mice treated with the methanol and aqueous extracts at $600 \mathrm{mg} / \mathrm{kg}$ survived longer $(10.60 \pm 0.51$ days for methanol extract and $9.60 \pm$ 0.51 day for aqueous extract) than those in the negative control group with mean survival time of $6.2 \pm 0.20$ days $(\mathrm{P}<0.05)$.

\section{Discussion}

In this study, the suppressive tests of extracts of the leaves of Acokanthera schimperi and Croton macrostachyus demonstrated a significant dose dependent chemosuppressive effect at various doses $(200,400,600 \mathrm{mg} / \mathrm{kg})$ for aqueous

Table 4 Effect of crude methanol and aqueous leaf extracts of Acokanthera schipmeri on body weight and PCV of $P$. berghei infected mice

\begin{tabular}{|c|c|c|c|c|c|}
\hline \multirow{2}{*}{$\begin{array}{l}\text { Extracts/ } \\
\text { Treatments }\end{array}$} & \multirow{2}{*}{$\begin{array}{l}\text { Dose } \\
(\mathrm{mg} / \mathrm{kg})\end{array}$} & \multicolumn{2}{|c|}{ PCV } & \multicolumn{2}{|c|}{ Body weight in grams } \\
\hline & & Day 0 & Day 4 & Day 0 & Day 4 \\
\hline \multirow[t]{3}{*}{ Methanol extracts } & 200 & $55.80 \pm 0.37$ & $49.20 \pm 2.71^{*}$ & $29.20 \pm 1.22$ & $29.08 \pm 1.09^{*}$ \\
\hline & 400 & $53.60 \pm 0.40$ & $52.80 \pm 1.50^{*}$ & $31.82 \pm 2.036$ & $31.34 \pm 2.34^{*}$ \\
\hline & 600 & $55.20 \pm 0.37$ & $46.20 \pm 3.39^{*}$ & $29.98 \pm 1.63$ & $29.88 \pm 0.89^{*}$ \\
\hline Distilled water & $1 \mathrm{~mL}$ & $55.20 \pm 1.11$ & $37.00 \pm 2.94^{\mathrm{a}}$ & $29.64 \pm 1.99$ & $26.96 \pm 2.26^{*}$ \\
\hline Chloroquine & 25 & $54.00 \pm 1.14$ & $55.60 \pm 1.50^{*}$ & $28.20 \pm 1.79$ & $28.68 \pm 2.10^{*}$ \\
\hline \multirow[t]{3}{*}{ Aqueous extracts } & 200 & $53.60 \pm 1.50$ & $49.20 \pm 1.80^{*}$ & $28.80 \pm 1.53$ & $28.90 \pm 1.55^{*}$ \\
\hline & 400 & $54.00 \pm 1.14$ & $48.60 \pm 1.69^{*}$ & $29.78 \pm 2.08$ & $28.14 \pm 1.61^{*}$ \\
\hline & 600 & $52.20 \pm 1.24$ & $45.20 \pm 2.92^{*}$ & $30.24 \pm 1.48$ & $28.52 \pm 1.48^{*}$ \\
\hline Distilled water & $1 \mathrm{~mL}$ & $55.20 \pm 1.11$ & $37.00 \pm 2.94^{\mathrm{a}}$ & $29.72 \pm 1.95$ & $26.90 \pm 2.28^{*}$ \\
\hline Chloroquine & 25 & $54.00 \pm 1.14$ & $55.60 \pm 1.50^{*}$ & $28.20 \pm 1.79$ & $28.68 \pm 2.10^{*}$ \\
\hline
\end{tabular}


Table 5 Suppressive effect of methanol extracts of Croton macrostachyus and mean survival time

\begin{tabular}{lllll}
\hline Group & Dose $(\mathbf{m g} / \mathbf{k g})$ & Antimalarial activities on Day-4 post infection & \% Suppression & $\begin{array}{l}\text { Mean } \\
\text { survival } \\
\text { time in } \\
\text { days }\end{array}$ \\
\cline { 3 - 4 } & & \% Parasitaemia \pm SEM & 0.00 & $7.20 \pm 0.37$ \\
\hline 1 & Distilled water $(1 \mathrm{~mL})$ & $46.86 \pm 1.03$ & 21.06 & $7.80 \pm 0.58^{\mathrm{b}}$ \\
3 & 200 & $38.56 \pm 3.07$ & 27.72 & $7.40 \pm 0.98^{\mathrm{b}}$ \\
4 & 400 & $33.88 \pm 5.75$ & 34.33 & $7.40 \pm 0.93^{\mathrm{b}}$ \\
5 & 600 & $30.80 \pm 5.56$ & 100.00 & $11.75 \pm 0.48^{*}$ \\
\hline
\end{tabular}

$\%$ parasitaemia and mean survival time results presented as mean $\pm S D ; n=5$; $=$ values are significantly different from that of the negative control; values with Superscript $b$ - are not significantly different from that of the negative control $(P>0.05)$.

and methanol extracts. The highest percentage chemosuppression was exhibited by the aqueous extract of Croton macrostachyus, followed by the methanol extract of A. schimperi at $600 \mathrm{mg} / \mathrm{kg}$.

Acute and sub-acute test results of the extracts of both plant species showed no sign of toxicity in all treated mice. The 4-day suppressive test is a standard test commonly used for antimalarial screening [24]. Extracts of C. macrostachyus and A. schimperi produced significant chemosuppression in all treated groups.

Antiplasmodial activity has been related to a range of several classes of secondary plant metabolites including alkaloids, sesquiterpenes, triterpenes, flavanoids, limonoids, quassinoids, xanthones, quinines and phenolic compounds of which alkaloids have been the most important and have shown very interesting activities $[8,29]$. Indeed, quinine is the first antimalarial drug that belongs to the class of alkaloids [30] Croton spp. generally contain diterpenoids, triterpenoids, alkaloids, flavonoids, lignoids and proanthocyanidins [31], which have strong antiplasmodial activity. Therefore, the antiplasmodial activity observed in this study may be attributed to the presence of these bioactive compounds.

Both the methanol and aqueous extracts of C. macrostachyus exhibited comparable suppressive effect on $P$. berghei. However, aqueous extract of Acokanthera schimperi in all doses tested may be considered to have lower activity i.e. $22.34 \%, 22.72 \%$ and $24.60 \%$ parasitaemia reduction at 200,400 and $600 \mathrm{mg} / \mathrm{kg}$, respectively. On the other hand, methanol extract can be considered active with $34.8 \%$ parasitaemia reduction at $600 \mathrm{mg} / \mathrm{kg}$ and $31.8 \%$ at $400 \mathrm{mg} / \mathrm{kg}$. Thus, the result of this study may justify the traditional use of the plant for antimalarial therapy in different parts of Ethiopia [13,14].

Methanol and aqueous extract of C. macrostachyus and $A$. schimperi prevented body weight loss. Result of similar study on crude extracts and solvent fractions of Croton macrostachyus revealed the significant prevention of weight loss associated with increase in parasitemia level [32].

Hematological abnormalities are considered a hallmark of malaria [33]. According to Iyawe and Onigbinde [34], Plasmodium berghei increases erythrocyte fragility and significantly reduces PCV in mice. Methanol and aqueous extracts of $A$. schimperi prevented PCV reduction in a dose dependent manner as compared to negative control group.

Another parameter used to evaluate the efficacy of antimalarial plant extracts in this study was mean survival time. A. schimperi significantly prolonged mice survival time compared to negative control group at $600 \mathrm{mg} / \mathrm{kg}$ and this could be attributed to parasitemia suppression effect of the extract of the plant. In contrast, all the doses of C. macrostachyus, which showed higher parasitemia suppression in this study, did not prolong mean survival time.

Table 6 Suppressive effect of aqueous extract of Croton macrostachyus and mean survival time

\begin{tabular}{lllll}
\hline Group & Dose $(\mathrm{mg} / \mathbf{k g})$ & \multicolumn{2}{c}{ Antimalarial activities on Day-4 post infection } & $\begin{array}{l}\text { Mean } \\
\text { survival } \\
\text { time in } \\
\text { days }\end{array}$ \\
\cline { 3 - 4 } & & \% Parasitaemia \pm SEM & $7.20 \pm 0.20$ \\
2 & Distilled water $(1 \mathrm{~mL})$ & $46.89 \pm 1.03$ & 0.00 & $7.40 \pm 0.98^{\mathrm{b}}$ \\
3 & 200 & $34.24 \pm 5.16$ & 26.14 & $7.80 \pm 0.37^{\mathrm{b}}$ \\
4 & 400 & $32.60 \pm 4.50$ & 30.50 & $7.40 \pm 0.60^{\mathrm{b}}$ \\
5 & 600 & $23.20 \pm 7.87$ & 50.53 & $11.75 \pm 0.48^{*}$ \\
\hline
\end{tabular}

$\%$ parasitaemia and mean survival time results presented as mean $\pm S D ; n=5 ;{ }^{*}=$ values are significantly different from that of the negative control; values with Superscript $b$ - are not significantly different from the negative control $(P>0.05)$. 
Table 7 Parasitaemia suppressive effect of methanol extract of Acokanthera schimperi and mean survival time

\begin{tabular}{lllll}
\hline Group & Dose $(\mathbf{m g} / \mathbf{k g})$ & \multicolumn{2}{l}{ Antimalarial activities on Day-4 post infection } & $\begin{array}{l}\text { Mean } \\
\text { survival } \\
\text { time in } \\
\text { days }\end{array}$ \\
\cline { 3 - 4 } & & \% Parasitaemia \pm SEM & 0.00 & $6.2 \pm 0.20$ \\
1 & Distilled water $(1 \mathrm{~mL})$ & $52.80 \pm 4.24$ & 22.7 & $7.00 \pm 1.73^{\mathrm{b}}$ \\
3 & 200 & $40.80 \pm 3.67$ & 31.8 & $7.20 \pm 1.3^{\mathrm{b}}$ \\
4 & 400 & $36.00 \pm 4.74$ & 34.8 & $10.60 \pm 0.51^{*}$ \\
5 & 600 & $34.40 \pm 2.87$ & 100.0 & $14.2 \pm 1.30^{*}$ \\
\hline
\end{tabular}

$\%$ parasitaemia and mean survival time results presented as mean $\pm S D ; n=5$; values with superscript $b$ are not significantly different from that of the negative control $(P>0.05)$. Values are significantly different as compared to that of negative controls $(P<0.05)$.

This may show that half-life of the active compounds in plasma metabolism is shorter [35].

Comparatively, the methanol extract of the leaves of C. macrostachyus showed lower antimalarial activity than its water extract counterpart. On the other hand, water extract of the leaves of Acokanthera schimperi showed lower activity compared to that of methanol. During extraction, solvents diffuse into the solid plant material and solubilize compounds with similar polarity [21]. This might indicate that the active compounds solubility which is responsible for the observed activity is different.

Chloroquine phosphate used in this study suppressed parasitaemia to non-detectable number, which is in agreement with [36] in which standard antimalarial drug cleared $P$. berghei, to undetectable level. The results of the acute toxicity within 24 hours revealed that no toxic effect or mortality was observed in mice treated orally with methanol and aqueous extracts of Croton macrostachyus and Acokanthera schimperi as a single dose of $2000 \mathrm{mg} /$ $\mathrm{kg}$, which the single highest dose is recommended by OECD Guidelines 425 for testing acute toxicity. In addition, no changes in general appearance or behavioral pattern were noted until the end of 14 days. Therefore, absence of mortality up to an oral dose of $2000 \mathrm{mg} / \mathrm{kg}$ could indicate that the test extracts are safe and this could in turn explain the safe use of the plants by local people in Ethiopia who have been using them in traditional management of malaria $[13,14]$.
The median lethal oral dose $\left(\mathrm{LD}_{50}\right)$ is greater than $2000 \mathrm{mg} / \mathrm{kg}$ if three or more animals survive [23]. No death was observed in the animals receiving the extracts up to a dose of $2000 \mathrm{mg} / \mathrm{kg}$ body weight, which is about 10 times the minimum effective dose tested $\left(200 \mathrm{mg} / \mathrm{kg}\right.$ ). If a test substance has $\mathrm{LD}_{50}$ higher than three times the minimum effective dose, it can be taken as a good candidate for further studies [26]. The extracts from this study are, therefore, good candidates for further studies.

Repeated dose toxicity studies provide information on the possible health hazards likely to arise from repeated exposure over a relatively limited period of time [37] and repeated daily dosing is more clinically relevant than acute toxicity study. In this study, a 4-day administration of the extracts of 500,750 and $1000 \mathrm{mg} / \mathrm{kg}$ daily revealed no sign of toxicity and all mice survived beyond the 30-days observation period.

According to Pillai et al. [38], the reduction in body weight is a simple and sensitive index of toxicity after exposure to toxic substances. In this study, there was no significant body weight change for aqueous and methanol extracts of $A$. schimperi and methanol extract of C. macrostachyus. Nevertheless, body weight loss in mice was observed at $1000 \mathrm{mg} / \mathrm{kg}$ in those treated with aqueous extract of C. macrostachyus. The decrease in body weight observed in the group treated with the highest dose could be attributed to the suppression of the animals' appetite by the extract.

Table 8 Parasitaemia suppressive effect of aqueous extract of Acokanthera schimperi and mean survival time

\begin{tabular}{lllll}
\hline Group & Dose $(\mathbf{m g} / \mathbf{k g})$ & \multicolumn{2}{l}{ Antimalarial activities on Day-4 post infection } & $\begin{array}{c}\text { Mean survival } \\
\text { Time in days }\end{array}$ \\
\cline { 3 - 4 } & & \% Parasitaemia \pm SEM & \% Suppression & $6.20 \pm 0.20$ \\
2 & Distilled Water $(1 \mathrm{~mL})$ & $52.80 \pm 4.24$ & 0.00 & $6.40 \pm 0.25^{\mathrm{b}}$ \\
3 & 200 & $41.0 \pm 3.89$ & 22.34 & $7.00 \pm 0.77^{\mathrm{b}}$ \\
4 & 400 & $40.80 \pm 1.65$ & 22.72 & $9.60 \pm 0.51^{*}$ \\
5 & 600 & $39.80 \pm 3.49$ & 24.60 & $14.20 \pm 0.58^{*}$ \\
\hline
\end{tabular}

$\%$ parasitaemia and mean survival time results presented as mean $\pm S D ; n=5$; values with Superscript $b$ are not significantly different from the negative control $(P>0.05) .{ }^{*}=$ there was a significant difference compared to negative controls $(P<0.05)$. 
Investigation of the hematological parameters can also be used to determine the extent of deleterious effect of foreign compound including plant extracts on the blood constituent of an animal. The hematological parameters of treated mice ( $\mathrm{Hb}$ and $\mathrm{PCV}$ of $A$. schimperi and PCV of C. macrostachyus), an index of anemia, did not show significant difference on day 4 compared to day 0 . Similarly, WBC, in case of C. macrostachyus treated mice, which is an important index of pathological and physiological status [28], exhibited no significant difference. This effect of the extract on the hematological parameters of the animals might be an indication that it is unlikely to be toxic.

\section{Conclusions}

The antimalarial activity test showed that both plants exhibited significant antiplasmodial activity as evidenced by their ability to suppress $P$. berghei infection in mice in a dose dependent manner, which may partly justify the claim by traditional practitioners about the use of these two plants against malaria. The study also revealed that the two plants are not toxic in both acute and sub-acute tests at the tested doses of the extracts. Further evaluation of these plants is, however, needed to isolate, identify and characterize the active ingredients responsible for the observed antimalarial activity of the plants.

Competing interests

The authors declare that they have no competing interests.

\section{Authors' contributions}

TM conceived the research idea, performed the experiment, analyzed and interpreted the data as well as prepared the first draft of the paper. MG \& BE conceived the research idea, and designed the experiment. All authors read and approved the final manuscript

\section{Acknowledgments}

We thank the Aklilu Lemma Institute of Pathology (ALIPB), Addis Ababa University, for material and financial support to conduct this study. Our thanks also go to Ethiopian Health and Nutrition Research Institute (EHNRI) for supplying us with the mice and $P$. berghei.

\section{Author details}

'Hosanna Health Science College, Hosanna, P.O. Box 159, SNNPR, Ethiopia.

${ }^{2}$ Aklilu Lemma Institute of Pathobiology, Addis Ababa University, P.O. Box

1176, Addis Ababa, Ethiopia.

Received: 22 January 2014 Accepted: 18 August 2014

Published: 26 August 2014

\section{References}

1. Bloland PB: Drug resistance in malaria. Geneva: World Health Organization; 2001. WHO/ CDS/CSR/DRS/2001/4.

2. WHO: World malaria Report, WHO Global Malaria Programme. Geneva: World Health Organization; 2011.

3. WHO: World Malaria Report, WHO Global Malaria Programme. Geneva: World Health Organization; 2013.

4. Otten M, Aregawi M, Were W, Karema C, Medin A, Bekele W, Jima D, Gausi K, Komatsu R, Korenromp E, Low-Beer D, Grabowsky M: Initial evidence of reduction of malaria cases and deaths in Rwanda and Ethiopia due to rapid scale-up of malaria prevention and treatment. Malar J 2009, 8:14
5. Petros Z: The need of standardized herbal remedies as alternate sources of antimalarial products in Ethiopia - updated review. Pharmacologyonl 2011, 3:1440-1447

6. Federal Ministry of Health (FMOH): National malaria guidelines. 3rd edition. Addis Ababa, Ethiopia: Federal Democratic Republic of Ethiopia, Ministry of Health; 2012

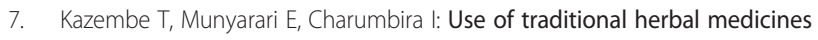
to cure malaria. BEPLS 2012, 1:63-85.

8. Dharani N, Rukunga G, Yenesew A, Mbora A, Mwaura L, Dawson I, Jamnadass R: Common Antimalarial Trees and Shrubs of East Africa. In a Description of Species and a Guide to Cultivation and Conservation Through Use. Edited by Dawson I. Nairobi, Kenya: The World Agroforestry Centre (ICRAF); 2010.

9. Adewunmi CO, Ojewole JAO: Safety of traditional medicines complementary and alternative medicines in Africa. Afr J Tradti Complement Altern Med 2004, 1:1-3.

10. Willcox ML, Bodeker G: Traditional herbal medicines for malaria. BMJ 2004, 329:1156-1159.

11. Abebe D, Ayehu A: Medicinal Plants and Enigmatic Health Practices of Northern Ethiopia. Addis Ababa, Ethiopia: BSPE; 1993.

12. Bekele E: Study on Actual Situation of Medicinal Plants in Ethiopia. Prepared for JAICAF 2007. Available on www.jaicaf.or.jp/publications/ethiopia ac.pdf.

13. Giday M, Teklehaymanot T, Animut A, Mekonnen $Y$ : Medicinal plants of the Shinasha, Agew-awi and Amhara peoples in northwest Ethiopia. J Ethnopharmacol 2007, 110:516-525

14. Mesfin A, Giday M, Anmut A, Teklehaymanot T: Ethnobotanical study of antimalarial plants in Shinile District, Somalia Region, Ethiopia, and in vivo evaluation of selected ones against Plasmodium berghei. $J$ Ethnopharmacol 2012, 139:221-227.

15. Sorsa S: In vitro evaluation of the activity of some Ethiopian traditional medicinal plants crude extracts against Plasmodium falciparum. MSc thesis: Department of Biology, Addis Ababa University; 1992.

16. Animut A: In vivo antimalarial screening of some Ethiopian traditional medicinal plants against Plasmodium bereghei in mouse system. Addis Ababa University: MSc thesis, Department of Biology; 2002.

17. Beourou S, Le Lamer A, Maurel-Chevalley S, Mutiso P, Souard F, Moulis C, Fabre $N$, Valentin A: Evaluation of the antiplasmodial activity of extracts of plants used in traditional medicine in Kenya. Int J Med Plants Res 2013, 2:219-224.

18. Boyom FF, Kemgne EM, Tepongning R, Mbacham WF, Tsamo E, Zollo PHA Antiplasmodial activity of extracts from seven medicinal plants used in malaria treatment in Cameroon. J Ethnopharmacol 2009, 123:483-488.

19. Innocent E, Moshi MJ, Masimba PJ, Mbwambo ZH, Kapingu MC, Kamuhabwa A: Screening of traditionally used plants for in vivo antimalarial activity in mice. Afr J Tradti Complement Altern Med 2009, 6:163-167.

20. Sasidharan S, Chen Y, Saravanan D, Sundram KM, Yoga Latha L: Extraction, isolation and characterization of bioactive compounds from Plants' extracts. Afr J Tradti Complement Alter Med 2011, 8:1-10.

21. Tiwari $P$, Kumar B, Kaur M, Kaur G, Kaur H: Phytochemical screening and extraction. A review IPS 2011, 1:98-106.

22. Moll K, Ljungström I, Perlmann H, Scherf A, Wahlgren M: Methods in Malaria Research. 5th edition. Virginia: Animal models. Experimental malaria: using blood stage infections of rodent Malaria. MR4/Atcc Manassas; 2008:147-148

23. OECD: OECD guideline for testing of chemicals. Acute Oral Toxicity - Up-andDown Procedure; 2008.

24. David AF, Philip JR, Simon IC, Reto B, Solomon N: Antimalarial drug discovery: efficacy models for compound screening. Nat Rev 2004, 3:509-520.

25. Hoff J, LVT, RLATG: Methods of blood collection in the mouse. Lab Animal 2000, 29:47-53.

26. Krettli AU, Adebayo JO, Krettli LG: Testing of natural products and synthetic molecules aiming at New antimalarials. Curr Drug Targ 2009, 10:261-270.

27. Mengistie B, Makonnen E, Urga K: In vivo antimalarial activity of Dodonaea Angustifolia seed extracts against plasmodium berghei in mice model. MEJS 2012, 4:47-63.

28. Cheesbrough M: District Laboratory Practice in Tropical Countries. Cambridge: Part 2. 2nd edition. Cambridge University Press; 2006.

29. Frederich $M$, Tits $M$, Angenot $L$ : Potential antimalarial activity of indole alkaloids. Trans R Soc Trop Med Hyg 2008, 102:11-19. 
30. Oliver AB, Dolabela MF, Braga FC, Jacome R, Varotti FP, Povoa MM:

Plant-derived antimalarial agents: new leads and efficient phythomedicines. Part I Alkaloids An Acad Bras Ciênc 2009, 81:715-740.

31. Salatino A, Maria L, Salatino F, Negri G: Traditional uses, chemistry and pharmacology of Croton species (Euphorbiaceae). J Braz Chem Soc 2007, 18:11-13.

32. Bantie L, Assefa S, Teklehaimanot T, Engidawork E: In vivo antimalarial activity of the crude leaf extract and solvent fractions of Croton macrostachyus Hocsht. (Euphorbiaceae) against Plasmodium berghei in mice. BMC Compl Alternative Med 2014, 14:79.

33. Lamikanra AA, Brown D, Potocnik A, Casals-Pascual C, Langhorne J, Roberts DJ: Malaria anemia of mice and men. Blood 2007, 110:18-28.

34. Iyawe HOT, Onigbinde AO: Impact of Plasmodium berghei and chloroquine on Haema antioxidant indices in mice. Asian J Biotechnol 2009, 4:30-35.

35. Franssen FJ, Smeijsters LW, Berger I, Aldana BM: In vitro and in vivo antiplasmodial activities of some plants traditionally used in Guatemala against malaria. Antimicrob Agents and Chemother 1997, 41:1500-1503.

36. Madara AA, Ajayi JA, Salawu OA, Tijani AY: Anti-malarial activity of ethanolic leaf extract of Piliostigma thonningii Schum. (Caesalpiniaceae) in mice infected with Plasmodium berghei berghei. Afr J Biotechnolo 2010 9:3475-3480.

37. OECD: OECD guideline for testing of chemicals. Combined repeated dose toxicity study with the reproduction/developmental toxicity screening test. 1992.

38. Pillai PG, Suresha P, Mishrab G, Annapurnaa M: Evaluation of the acute and sub-acute toxicity of the methanolic leaf extract of Plectranthus amboinicus (Lour) Spreng in Balb C mice. Eur J Exp Biol 2011, 1:236-245.

doi:10.1186/1472-6882-14-314

Cite this article as: Mohammed et al.: Evaluation of antimalarial activity of leaves of Acokanthera schimperi and Croton macrostachyus against Plasmodium berghei in Swiss albino mice. BMC Complementary and Alternative Medicine 2014 14:314.

\section{Submit your next manuscript to BioMed Central and take full advantage of:}

- Convenient online submission

- Thorough peer review

- No space constraints or color figure charges

- Immediate publication on acceptance

- Inclusion in PubMed, CAS, Scopus and Google Scholar

- Research which is freely available for redistribution 